Article

\title{
Karyotype Organization of the Endangered Species Yellow Cardinal (Gubernatrix cristata)
}

\author{
Sandra Eloisa Bülau ${ }^{1}$, Rafael Kretschmer ${ }^{2, *}{ }^{\mathbb{D}}$, Ivanete de Oliveira Furo ${ }^{3}$, \\ Edivaldo Herculano Correa de Oliveira ${ }^{4,5}$ and Thales Renato Ochotorena de Freitas ${ }^{2}$
}

1 Laboratório de Citogenética e Evolução, Departamento de Zoologia, Instituto de Biociências, Universidade Federal do Rio Grande do Sul, Porto Alegre 91540-000, Rio Grande do Sul, Brazil; sbulau@yahoo.com.br

2 Laboratório de Citogenética e Evolução, Departamento de Genética, Instituto de Biociências, Universidade Federal do Rio Grande do Sul, Porto Alegre 91509-900, Rio Grande do Sul, Brazil; thales.freitas@ufrgs.br

3 Programa de Pós-Graduação em Genética e Biologia Molecular, Universidade Federal do Pará, Belém 66075-110, Pará, Brazil; ivanetefuro100@gmail.com

4 Laboratório de Cultura de Tecidos e Citogenética, SAMAM, Instituto Evandro Chagas, Ananindeua 67030-000, Pará, Brazil; ehco@ufpa.br

5 Instituto de Ciências Exatas e Naturais, Universidade Federal do Pará, Belém 66075-110, Pará, Brazil

* Correspondence: rafa.kretschmer@hotmail.com

Citation: Bülau, S.E.; Kretschmer, R.; Furo, I.d.O.; de Oliveira, E.H.C.;

de Freitas, T.R.O. Karyotype

Organization of the Endangered

Species Yellow Cardinal (Gubernatrix

cristata). DNA 2021, 1, 77-84.

https://doi.org/10.3390/dna1020008

Academic Editor:

Marta Farré-Belmonte

Received: 8 September 2021

Accepted: 25 October 2021

Published: 27 October 2021

Publisher's Note: MDPI stays neutral with regard to jurisdictional claims in published maps and institutional affiliations.

Copyright: (c) 2021 by the authors. Licensee MDPI, Basel, Switzerland. This article is an open access article distributed under the terms and conditions of the Creative Commons Attribution (CC BY) license (https:/ / creativecommons.org/licenses/by/ $4.0 /)$.

\begin{abstract}
Karyotypic analyses have several applications in studies of chromosome organization, evolution, and cytotaxonomy. They are also essential to genome assembly projects. Here, we present for the first time the karyotype description of the endangered species yellow cardinal, Gubernatrix cristata (Passeriformes, Thraupidae), using conventional staining with Giemsa and 18S rDNA probes. This species has 78 chromosomes, with 12 pairs of macrochromosomes and 27 microchromosome pairs. The $18 \mathrm{~S}$ rDNA clusters were found in four microchromosomes. Our results revealed that G. cristata has a typical avian karyotype (approximately 80 chromosomes). However, G. cristata has an apomorphic state in relation to the $18 \mathrm{~S}$ rDNA distribution since the ancestral condition corresponds to only two microchromosomes with these sequences. Probably, duplications and translocations were responsible for increasing the number of $18 \mathrm{~S}$ rDNA clusters in G. cristata. The results were compared and discussed with respect to other Thraupidae and Passeriformes members. Considering the globally threatened status of G. cristata, we believe that its karyotype description could be a starting point for future cytogenetics and sequencing projects.
\end{abstract}

Keywords: Thraupidae; genome; avian chromosomes; rDNA

\section{Introduction}

The field of Avian cytogenetics is still new. To date, only $9.83 \%$ of bird species have had their karyotypes described [1]. Although Passeriformes represent the order with the largest number of species karyotyped (460), this number represents only $7 \%$ of the species from the order [1], indicating that the chromosome organization and evolution in this group remain largely unknown. Considering the Thraupidae family, $11.8 \%$ of approximately 380 species have had their karyotypes described [1].

Karyotypic analyses have been used for decades in studies of chromosome organization, evolution, and cytotaxonomy in birds [2,3]. The karyotypes are also important for confirming the number of chromosomes found during genome sequencing and assembly. For instance, the number of assembled chromosomal groups for the canary (Serinus canaria) using whole-genome shotgun sequencing was $35(2 n=70)$; however, the cytogenetic analysis via conventional staining with Giemsa showed that the correct number of chromosomes is $40(2 \mathrm{n}=80)$ [4]. This difference is due to the large number of microchromosomes [4], the high GC content [5], and the presence of tandem repeats [6] in avian species. These findings highlight the importance of karyotype description for the correct assembling of chromosomes. 
The yellow cardinal (Gubernatrix cristata) is a member of the Tharaupidae (Passeriformes, Oscines). The species is globally threatened and qualified as Endangered due to constant population decline [7]. The main threats are habitat loss, mainly due to the conversion of native fields into agricultural areas [8-10], and trapping, especially of males, for the illegal trade of birds [10-12].

The species occurs in the Pampa Biome, in southern South America. It is strongly associated with the savanna-park-type vegetation, present in large parts of Argentina and Uruguay and a few sites in the Rio Grande do Sul State, Brazil [13-16]. G. cristata has always been rare throughout its distribution; currently, the records are sparse and restricted to difficult-to-access points or legally protected areas [17-19]. This is the case in Brazil, where the only population, with about 50 specimens, is found in Espinilho State Park and its surrounding areas $[20,21]$.

Due to its threat level, the species was included in a Brazilian national action plan aimed at the conservation of endangered passerines of the Campos Sulinos in Brazil. This action plan has, among its goals, the surveying of the populations and genetic data of the birds and the application of the results to improve proposals for management and conservation measures in the region [20].

There are no previous cytogenetic studies of G. cristata. Hence, in this study, we have performed a karyotype description including the distribution of $18 \mathrm{~S}$ rDNA clusters in this species. Our aim was to provide cytogenetic information on this endangered species, which may be useful for future studies, especially genome assembly. In addition, we have compared our results with those of other Passeriformes species, especially Thraupidae members.

\section{Materials and Methods}

\subsection{Animal}

One male individual of G. cristata was used in this study. The animal was maintained in the Animal Screening Center (Centro de Triagem de Animais Silvestres) of Porto Alegre, Rio Grande do Sul State, in 2014. The animal was sent to the Center by the "Instituto Brasileiro do Meio Ambiente e dos Recursos Naturais", having been captured during inspection activities carried out by the agency.

\subsection{Cell Culture and Karyotype Description}

A cell culture was established from feather pulp from the male individual of G. cristata, following [22]. Briefly, the feather pulp was dissociated mechanically and with type IV collagenase for one hour. The cell suspension obtained was cultured in Dulbecco's modified Eagle's medium (DMEM) supplemented with $15 \%$ of fetal bovine serum, $2 \%$ of penicillin streptomycin, and $1 \%$ of L-glutamine at $37{ }^{\circ} \mathrm{C}$. Metaphase chromosome spreads were obtained after colcemid treatment $(1 \mathrm{~h})$, hypotonic solution $(0.075 \mathrm{M} \mathrm{KCl}, 15 \mathrm{~min})$, and fixation with 3:1 methanol/acetic acid. The diploid number and chromosome morphology were determined in at least 20 metaphase plates stained with Giemsa $(10 \%$ in $0.07 \mathrm{M}$ phosphate buffer, at $\mathrm{pH}$ 6.8). The chromosomal morphology determination followed Guerra [23].

\subsection{The $18 S$ rDNA Clusters in Gubernatrix cristata and in Passeriformes Species}

Biotin-labeled $18 \mathrm{~S}$ rDNA probes were used to determine the distribution of ribosomal RNA gene clusters in G. cristata. The ribosomal fragments were amplified by PCR using primers NS1 5' -GTA GTC ATA TGC TTG TCT C-3' and NS8 5'-TCC GCA GGT TCA CCT ACG GA-3' and nuclear DNA of Ocyurus chrysurus (Perciformes: Lutjanidae) [24], labeled via nick translation (Roche, Mannheim, Germany) and detected with streptavidin-Cy3, following the manufacturer's instructions. Hybridization, stringency washes, and detection followed Daniels and Delany [25]. The results were analyzed using a Zeiss Axioplan 2 fluorescent microscope and AxioVision 4.8 software (Zeiss, Jena, Germany).

To perform a comparison of the rDNA distribution among Passeriformes, we searched in the National Center for Biotechnology Information (NCBI) database for studies that have 
addressed this theme. The following keywords were used: "18S rDNA in Passeriformes" and "FISH with 18S rDNA probes in Passeriformes". A phylogenetic tree of the Passeriformes species with respect to the $18 \mathrm{~S}$ rDNA FISH results was sourced from the TimeTree database (http:/ / www.timetree.org, accessed on 8 September 2021) [26].

\section{Results}

\subsection{The Karyotype of G. cristata}

The G. cristata individual analyzed here showed 78 chromosomes, with 12 pairs of macrochromosomes including the $\mathrm{Z}$ chromosome, and 27 microchromosome pairs (Figure 1). The first 6 pairs were submetacentric. The remaining autosomes were considered as telocentric. The $\mathrm{Z}$ chromosome was submetacentric.

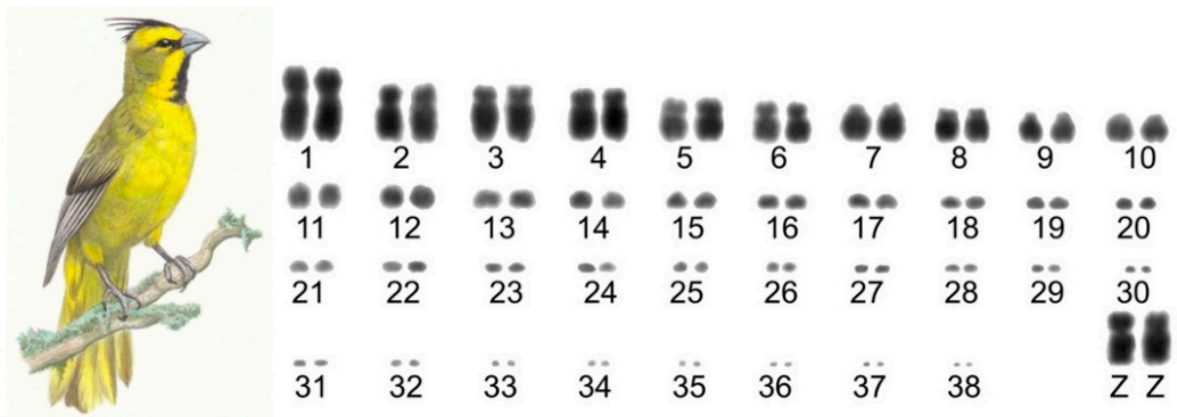

Figure 1. Complete karyotype of a male Gubernatrix cristata $(2 \mathrm{n}=78)$, with conventional Giemsa staining.

\subsection{The $18 \mathrm{~S}$ rDNA Distribution in G. cristata}

FISH experiments with $18 \mathrm{~S}$ rDNA probes indicated that these sequences are distributed in four microchromosomes (two pairs) in G. cristata (Figure 2).

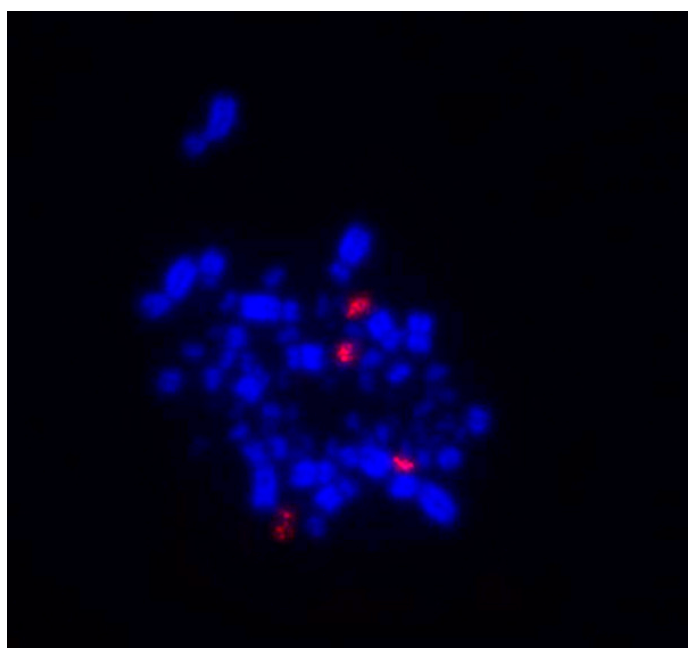

Figure 2. $18 \mathrm{~S}$ rDNA distribution in Gubernatrix cristata, found in four microchromosomes (two pairs).

\subsection{Comparisions of $18 S$ rDNA Distribution among Passeriformes Species}

Our searches in the NCBI database resulted in a total of 10 papers, corresponding to 27 Passeriformes species in which the $18 \mathrm{~S}$ rDNA distribution had been determined, including the present study (Table 1). The most frequent number of chromosomes with $18 \mathrm{~S}$ rDNA clusters was two microchromosomes, however, some species showed a higher number of chromosomes, such as four and six microchromosomes. Only four species from the Thraupidae family have had the $18 \mathrm{~S}$ rDNA clusters characterized: Saltator aurantiirostris, Tachyphonus coronatus, and Coryphospingus cucullatus with two microchromosomes with 
these sequences, and G. cristata with four microchromosomes. To better illustrate the $18 \mathrm{~S}$ rDNA distribution among Passeriformes species, the numbers of chromosomes with these sequences were plotted in a phylogenetic tree (Figure 3).

Table 1. List of Passeriformes species with $18 \mathrm{~S}$ rDNA chromosome mapping.

\begin{tabular}{|c|c|c|c|c|c|}
\hline Species & Family & Suborder & $\mathrm{No}^{1}$ & Diploid Number & Reference \\
\hline Syndactila rufosuperciliata & Furnariidae & Suboscines & 2 micros & 82 & [27] \\
\hline Cranioleuca obsoleta & Furnariidae & Suboscines & 2 micros & 82 & [27] \\
\hline Furnarius rufus & Furnariidae & Suboscines & 2 micros & 82 & [27] \\
\hline Synallaxis albescens & Furnariidae & Suboscines & 2 micros & 82 & [27] \\
\hline Anumbius annumbi & Furnariidae & Suboscines & 2 micros & 82 & [27] \\
\hline Dendrocolaptes platyrostris & Furnariidae & Suboscines & 2 macros & 82 & [27] \\
\hline Glyphorynchus spirurus & Furnariidae & Suboscines & 2 macros & 80 & [28] \\
\hline Schiffornis virescens & Tityridae & Suboscines & 2 micros & 82 & [27] \\
\hline Myiarchus ferox & Tyrannidae & Suboscines & 2 micros & 76 & [27] \\
\hline Pitangus sulphuratus & Tyrannidae & Suboscines & 2 micros & 80 & [29] \\
\hline Satrapa icterophrys & Tyrannidae & Suboscines & 2 micros & 82 & [29] \\
\hline Serpophaga subcristata & Tyrannidae & Suboscines & 4 micros & 82 & [29] \\
\hline Elaenia spectabilis & Tyrannidae & Suboscines & 4 micros & 80 & [30] \\
\hline Conopophaga lineata & Conopophagidae & Suboscines & 2 micros & 78 & [31] \\
\hline Taeniopygia guttata & Estrildidae & Oscines & 2 micros & 80 & [32] \\
\hline Basileuterus culicivorus & Parulidae & Oscines & 2 micros & 80 & [27] \\
\hline Serinus canaria & Fringillidae & Oscines & 4 micros & 80 & [32] \\
\hline Agelaioides badius & Icteridae & Oscines & 4 micros & 80 & [27] \\
\hline Molothrus bonariensis & Icteridae & Oscines & 2 micros & 80 & [27] \\
\hline Turdus rufiventris & Turdidae & Oscines & 6 micros & 78 & [33] \\
\hline Turdus albicollis & Turdidae & Oscines & 4 micros & 78 & [33] \\
\hline Zonotrichia capensis & Passerellidae & Oscines & 2 micros & 80 & [34] \\
\hline Saltator similis & Thraupidae & Oscines & 2 micros & 80 & [35] \\
\hline Saltator aurantiirostris & Thraupidae & Oscines & 2 micros & 80 & [35] \\
\hline Tachyphonus coronatus & Thraupidae & Oscines & 2 micros & 80 & [27] \\
\hline Coryphospingus cucullatus & Thraupidae & Oscines & 2 micros & 80 & [27] \\
\hline Gubernatrix cristata & Thraupidae & Oscines & 4 micros & 78 & Present study \\
\hline
\end{tabular}

${ }^{1}$ Number of chromosomes with $18 / 28$ S rDNA clusters.

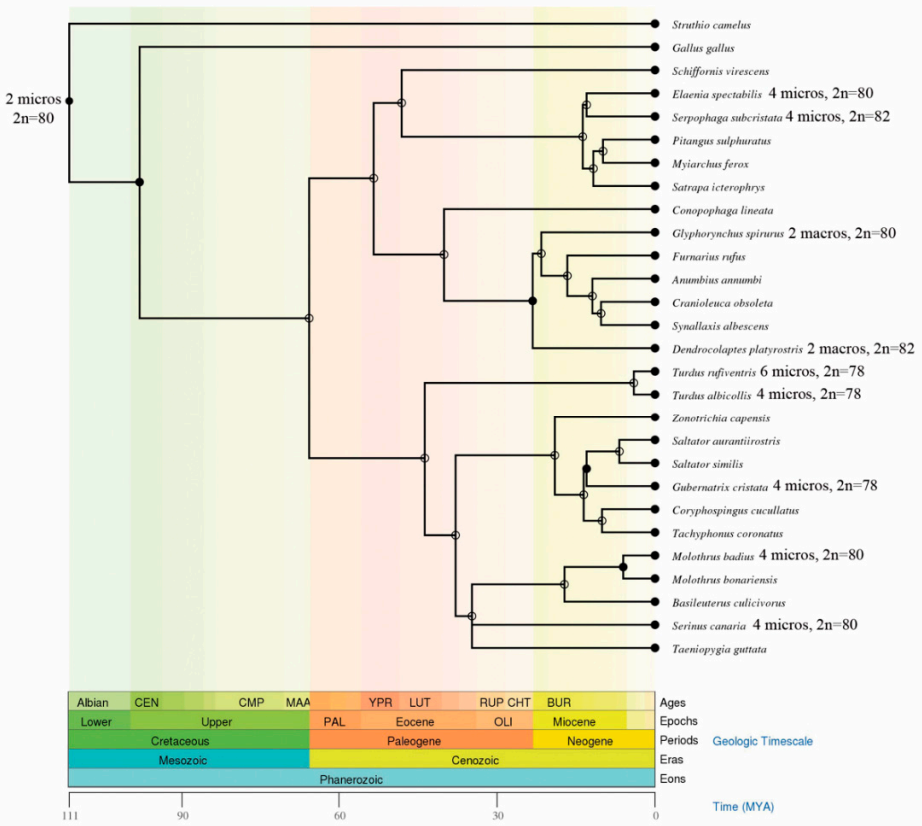

Figure 3. Phylogeny of the Passeriformes species with $18 \mathrm{~S}$ rDNA from FISH results. Most of the species have the ancestral state (two microchromosomes). Species with apomorphic condition are indicated in the respective branches. The phylogenetic tree was sourced from the TimeTree database (http:/ / www.timetree.org, accessed on 8 September 2021) [26].

\section{Discussion}

With the recent advent of increasingly cost-effective high-throughput sequencing, most assembled genomes often lack a basic physical map or even information about chromosome numbers and morphology [36], especially in birds, due to the high number of 
microchromosomes [4], the high GC content [5], and the presence of tandem repeats [6]. A direct information link between the assembled genomes and the standard karyotype of the target species is not always provided. Hence, cytogenetic analyses are an important method of understanding the connections between the DNA and chromosomal structure.

In this study, we present the first karyotype description of the endangered species yellow cardinal (Gubernatrix cristata). The karyotype of G. cristata is composed of 78 chromosomes, which is a typical avian karyotype, since approximately $61 \%$ of the total number of species karyotyped showed a diploid number between 76 and 82 [1]. This is also a typical karyotype in Passeriformes members [1,28-35].

Regarding the chromosomal morphology variation in Thraupidae karyotypes, the first four pairs generally seem to vary frequently between metacentric, submetacentric, and acrocentric [35,37]. These changes may indicate intrachromosomal rearrangements, such as pericentric inversions, considering that the sizes of these chromosomes are highly conserved in these birds. In fact, previous studies have indicated that this type of rearrangement is frequent among Passeriformes, both with in situ [29-35] and in silico experiments $[38,39]$.

Usually, most of the avian species have the $18 \mathrm{~S}$ rDNA clusters in one pair of microchromosomes, including in the basal species (Paleognathae) [27,40]. Therefore, this state can be considered a plesiomorphic (ancestral) condition. However, it is possible to observe apomorphic states in some species, as the $18 \mathrm{~S}$ clusters are present in a higher number of microchromosome pairs. In addition, in other cases, these clusters can be found in macrochromosomes [27]. In G. cristata, the 18S rDNA clusters were found in four microchromosomes. Probably, the extra clusters in G. cristata resulted from duplication of rDNA sites and redistribution via translocation [41], since the increase in the number of chromosome pairs bearing $18 \mathrm{~S}$ rDNA is not related to a high diploid number (Table 1, Figure 3). Interestingly, previous studies have demonstrated that four Thraupidae members (Saltator similis, Saltator aurantiirostris, Tachyphonus coronatus, and Coryphospingus cucullatus) share the ancestral state $[27,35]$. Hence, we propose that the common ancestor of Thraupidae members had the ancestral condition, and duplication and translocation events increased the number of ribosomal clusters in G. cristata. Future studies are necessary to investigate the $18 \mathrm{~S}$ rDNA state in other Thraupidae members. Moreover, most of the Passeriformes families that have been investigated with ribosomal probes also have the ancestral state of the 18S rDNA cluster (Table 1), indicating that the common ancestor of Passeriformes had the ancestral state, while duplication and translocations of these sequences occurred independently in some lineages (Table 1).

In conclusion, we demonstrated that G. cristata has a typical avian diploid number and an apomorphic condition of $18 \mathrm{~S}$ rDNA clusters. Furthermore, we proposed that chromosomal rearrangements, such as duplication and translocation, were the main mechanisms responsible for redistribution of the clusters of $18 \mathrm{~S}$ in G. cristata. Our data represent a starting point for understanding the genome organization and evolution of this endangered species.

Author Contributions: Conceptualization, S.E.B., R.K. and T.R.O.d.F.; methodology, S.E.B., I.d.O.F. and R.K.; validation, S.E.B. and R.K.; formal analysis, S.E.B. and R.K.; investigation, S.E.B., I.d.O.F. and R.K.; resources, E.H.C.d.O. and T.R.O.d.F.; data curation, S.E.B. and R.K.; writing-original draft preparation, S.E.B., I.d.O.F. and R.K.; writing-review and editing, S.E.B., I.d.O.F., E.H.C.d.O., T.R.O.d.F. and R.K.; visualization, S.E.B. and R.K.; supervision, R.K. and T.R.O.d.F.; project administration, R.K. and T.R.O.d.F.; funding acquisition, E.H.C.d.O. and T.R.O.d.F. All authors have read and agreed to the published version of the manuscript.

Funding: This study was supported by Coordenação de Aperfeiçoamento de Pessoal de Nível Superior (CAPES) and Fundação de Amparo a Pesquisa do Estado do Rio Grande do Sul (FAPERGS/PRONEX 16/2551-00000485-4).

Institutional Review Board Statement: This work was carried out with the authorization of "Instituto Brasileiro do Meio Ambiente e dos Recursos Naturais (IBAMA)—Sistema de Autorização e 
Informação em Biodiversidade (SISBio)" under licenses $N^{\circ}$ 40312-1 and 40312-2. The experiments followed protocols approved by the Animal Use Ethics Committee of the Universidade Federal do Rio Grande do Sul (project 26466).

Informed Consent Statement: Not applicable.

Data Availability Statement: The data presented in this study are available in the article.

Acknowledgments: The authors would like to thank Cetas Porto Alegre and Cemave for the samples and the SISBIO for authorization for the sampling of the specimen examined in this study. We also would like to thank the Instituto Evandro Chagas, Ananindeua, Pará for technical support. We are also grateful to Alex Pinheiro de Araújo for the illustration of the Gubernatrix cristata used in Figure 1 and in the graphical abstract, and the Gallus gallus used in the graphical abstract.

Conflicts of Interest: The authors declare no conflict of interest and the funders had no role in the design of the study, in the collection, analyses, or interpretation of data, in the writing of the manuscript or in the decision to publish the results.

\section{References}

1. Degrandi, T.M.; Barcellos, S.; Costa, A.; Garnero, A.; Hass, I.; Gunski, R.J. Introducing the Bird Chromosome Database: An Overview of Cytogenetic Studies in Birds. Cytogenet. Genome Res. 2020, 160, 199-205. [CrossRef]

2. Griffin, D.; Robertson, L.; Tempest, H.; Skinner, B. The evolution of the avian genome as revealed by comparative molecular cytogenetics. Cytogenet. Genome Res. 2007, 117, 64-77. [CrossRef] [PubMed]

3. Kretschmer, R.; Ferguson-Smith, M.A.; De Oliveira, E.H.C. Karyotype Evolution in Birds: From Conventional Staining to Chromosome Painting. Genes 2018, 9, 181. [CrossRef] [PubMed]

4. Frankl-Vilches, C.; Kuhl, H.; Werber, M.; Klages, S.; Kerick, M.; Bakker, A.; De Oliveira, E.H.C.; Reusch, C.; Capuano, F.; Vowinckel, J.; et al. Using the canary genome to decipher the evolution of hormone-sensitive gene regulation in seasonal singing birds. Genome Biol. 2015, 16, 19. [CrossRef]

5. Peona, V.; Weissensteiner, M.H.; Suh, A. How complete are "complete" genome assemblies?-An avian perspective. Mol. Ecol. Resour. 2018, 18, 1188-1195. [CrossRef] [PubMed]

6. Beauclair, L.; Ramé, C.; Arensburger, P.; Piégu, B.; Guillou, F.; Dupont, J.; Bigot, Y. Sequence properties of certain GC rich avian genes, their origins and absence from genome assemblies: Case studies. BMC Genom. 2019, 20, 1-16. [CrossRef]

7. Birdlife International. Scientists Discover an "Invisible Barrier" that Holds the Answer to One of Nature's Little Mysteries. Birdlife News Posts. 16 March 2012. Available online: http:/ / www.birdlife.org (accessed on 14 June 2012).

8. Pessino, M.E.M. Nuevo registro y descripcion de hibridos entre cardenal amarillo (Gubernatrix cristata) y diuca comun (Diuca diuca) en la provincia de La Pampa, Argentina. Rev. Nuestras Aves 2006, 52, 16-18.

9. Martins-Ferreira, C.; Repenning, M.; Damiani, R.V. Gubernatrix cristata. In Plano de Ação Nacional Para a Conservação Daos Passeriformes Ameaçados Dos Campos Sulinos E Espinilho; Serafini, P.P., Ed.; Instituto Chico Mendes de Conservação da Biodiversidade ICMBio: Brasília, Brazil, 2013; pp. 116-119.

10. Domínguez, M.; Tiedemann, R.; Reboreda, J.C.; Segura, L.; Tittarelli, F.; Mahler, B. Genetic structure reveals management units for the yellow cardinal (Gubernatrix cristata), endangered by habitat loss and illegal trapping. Conserv. Genet. 2017, 18, 1131-1140. [CrossRef]

11. Chebez, J.C. Los Que Se Van: Especies Argentinas En Peligro; Albatros: Buenos Aires, Argentina, $1994 ;$ p. 604.

12. Ortiz, D. Distribucion historica y actual del cardenal amarillo (Gubernatrix cristata) en el litoral luvial argentino. In Temas de la Biodiversidad del Litoral Luvial Argentino, III; Acenolaza, F.G., Ed.; INSUGEO: San Miguel de Tucumán, Argentina, 2008; pp. 121-126.

13. Ridgely, R.S.; Tudor, G. The Birds of South America; University of Texas Press: Austin, TX, USA, 1989; Volume I, p. 516.

14. Azpiroz, A.B. Aves del Uruguay: Lista E Introduccion A su Biologia Y Conservacion; Aves Uruguay-GUPECA: Montevideo, Uruguay, 2003; p. 104.

15. Bencke, G.A. Diversidade e conservação da fauna dos Campos do Sul do Brasil. In Campos Sulinos: Conservação e uso Sustentável da Biodiversidade; Pillar, V.D.P., Muller, S.C., Castilhos, Z.M.d.S., Jacques, A.V.A., Eds.; MMA: Brasília, Brazil, 2009 ; pp. $101-121$.

16. Martins-Ferreira, C.; Santos, M.O.; Hadddrath, O.; Baker, A.J.; de Freitas, T.R.O. Isolation and characterization of 10 mi-crosatellite loci in the Yellow Cardinal Gubernatrix cristata En. Mol. Ecol. Resour. 2010, 10, 751-754.

17. Fontana, C.S.; Bencke, G.A.; Reis, R.E. Livro Vermelho da Fauna Ameaçada de Exatianção No Rio Grande Do Sul; EDIPUCRS: Porto Alegre, Brazil, 2003; p. 632.

18. Di Giacomo, A.S. Areas Importantes Para La Conservacion de Las Aves En Argentina: Sitios Prioritarios Para la Conservacion de la Biodiversidad. TEMAS De Naturaleza Y Conservacion, 5th ed.; Aves Argentinas/Asociacion Ornitologica del Plata: Buenos Aires, Argentina, 2005.

19. Dominguez, M.; Lapido, R.; Gorrindo, A.; Archuby, D.; Correa, E.; Llanos, F.; Reales, F.; Piantanida, F.; Marateo, G.; Meriggi, J.; et al. A citizen science survey discloses the current distribution of the endangered Yellow Cardinal Gubernatrix cristata in Argentina. Bird Conserv. Int. 2020, 31, 139-150. [CrossRef] 
20. Martins-Ferreira, C.; Bencke, G.A.; Fontana, C.S.; Dias, R.A.; Repenning, M.; Damiani, R.V.; Mauricio, G.N.; Gianuca, A.T.; Franz, I.; Rovedder, C.E.; et al. Plano de Ação Nacional Para a Conservação Dos Passeriformes Ameaçados dos Campos Sulinos e Espinilho; Instituto chico mendes de Conservação da Biodiversidade, ICMBio: Brasília, Brazil, 2013; p. 212.

21. Beier, C.; Repenning, M.; Da Pereira, M.S.; Pereira, A.; Fontana, C.S. Cooperative breeding and demography of Yellow Cardinal Gubernatrix cristata in Brazil. Rev. Bras. Ornitol. 2017, 25, 12-19. [CrossRef]

22. Furo, I.D.O.; Kretschmer, R.; Dos Santos, M.S.; Carvalho, C.A.D.L.; Gunski, R.J.; O’Brien, P.C.; Ferguson-Smith, M.A.; Cioffi, M.B.; De Oliveira, E.H. Chromosomal Mapping of Repetitive DNAs in Myiopsitta monachus and Amazona aestiva (Psittaciformes, Psittacidae) with Emphasis on the Sex Chromosomes. Cytogenet. Genome Res. 2017, 151, 151-160. [CrossRef] [PubMed]

23. Guerra, M.S. Reviewing the chromosome nomenclature of Levan et al. Rev. Bras. Genet. 1986, 9, 741-743.

24. White, T.J.; Bruns, T.; Lee, S.; Taylor, J. Amplification and direct sequencing of fungal ribosomal RNA genes for phylogenet-ics. In PCR Protocols: A Guide to Methods and Applications; Innis, M.A., Gelfand, D.H., Shinsky, J.J., White, T.J., Eds.; Academic Press: San Diego, CA, USA, 1990; pp. 315-322.

25. Daniels, L.M. Molecular and cytogenetic organization of the 5 S ribosomal DNA array in chicken (Gallus gallus). Chromosome Res. 2003, 11, 305-317. [CrossRef] [PubMed]

26. Kumar, S.; Stecher, G.; Suleski, M.; Hedges, S.B. TimeTree: A Resource for Timelines, Timetrees, and Divergence Times. Mol. Biol. Evol. 2017, 34, 1812-1819. [CrossRef] [PubMed]

27. Degrandi, T.M.; Gunski, R.J.; Garnero, A.D.V.; De Oliveira, E.H.C.; Kretschmer, R.; De Souza, M.S.; Barcellos, S.A.; Hass, I. The distribution of $45 \mathrm{~S}$ rDNA sites in bird chromosomes suggests multiple evolutionary histories. Genet. Mol. Biol. 2020, 43, e20180331. [CrossRef] [PubMed]

28. Ribas, T.; Nagamachi, C.Y.; Aleixo, A.; Pinheiro, M.L.S.; O’brien, P.C.M.; Ferguson-Smith, M.A.; Yang, F.; Suarez, P.; Pieczarka, J.C. Chromosome painting in Glyphorynchus spirurus (Vieillot, 1819) detects a new fission in Passeriformes. PLoS ONE 2018, 13, e0202040. [CrossRef]

29. Rodrigues, B.S.; Kretschmer, R.; Gunski, R.J.; Garnero, A.; O’Brien, P.C.; Ferguson-Smith, M.; De Oliveira, E.H. Chromosome Painting in Tyrant Flycatchers Confirms a Set of Inversions Shared by Oscines and Suboscines (Aves, Passeriformes). Cytogenet. Genome Res. 2017, 153, 205-212. [CrossRef] [PubMed]

30. Kretschmer, R.; De Oliveira, E.H.C.; Dos Santos, M.S.; Furo, I.D.O.; O’Brien, P.C.M.; Ferguson-Smith, M.A.; Garnero, A.; Gunski, R.J. Chromosome mapping of the large elaenia (Elaenia spectabilis): Evidence for a cytogenetic signature for passeriform birds? Biol. J. Linn. Soc. 2015, 115, 391-398. [CrossRef]

31. De Oliveira, T.D.; Kretschmer, R.; Bertocchi, N.; O’Brien, P.C.; Ferguson-Smith, M.A.; Garnero, A.D.V.; De Oliveira, E.H.C.; Gunski, R.J. The molecular cytogenetic characterization of Conopophaga lineata indicates a common chromosome rearrangement in the Parvorder Furnariida (Aves, Passeriformes). Genet. Mol. Biol. 2020, 43, e20200018. [CrossRef]

32. Santos, M.D.S.D.; Kretschmer, R.; Frankl-Vilches, C.; Bakker, A.; Gahr, M.; O’brien, P.C.M.; Ferguson-Smith, M.A.; De Oliveira, E.H.C. Comparative cytogenetics between two important songbird, models: The zebra finch and the canary. PLoS ONE 2017, 12, e0170997. [CrossRef]

33. Kretschmer, R.; Gunski, R.J.; Garnero, A.; Furo, I.D.O.; O’Brien, P.C.M.; Ferguson-Smith, M.A.; De Oliveira, E.H.C. Molecular Cytogenetic Characterization of Multiple Intrachromosomal Rearrangements in Two Representatives of the Genus Turdus (Turdidae, Passeriformes). PLoS ONE 2014, 9, e103338. [CrossRef] [PubMed]

34. Bülau, S.E.; Kretschmer, R.; Gunski, R.J.; Garnero, A.; O’Brien, P.C.M.; Ferguson-Smith, M.A.; De Oliveira, E.H.C.; De Freitas, T.R.O. Chromosomal polymorphism and comparative chromosome painting in the rufous-collared sparrow (Zonotrichia capensis). Genet. Mol. Biol. 2018, 41, 799-805. [CrossRef] [PubMed]

35. Santos, M.D.S.D.; Kretschmer, R.; Silva, F.A.O.; Ledesma, M.A.; O’Brien, P.C.M.; Ferguson-Smith, M.A.; Garnero, A.; De Oliveira, E.H.C.; Gunski, R.J. Intrachromosomal rearrangements in two representatives of the genus Saltator (Thraupidae, Passeriformes) and the occurrence of heteromorphic Z chromosomes. Genetica 2015, 143, 535-543. [CrossRef] [PubMed]

36. Deakin, J.E.; Potter, S.; O’Neill, R.; Ruiz-Herrera, A.; Cioffi, M.B.; Eldridge, M.D.; Fukui, K.; Graves, J.A.M.; Griffin, D.; Grutzner, F.; et al. Chromosomics: Bridging the Gap between Genomes and Chromosomes. Genes 2019, 10, 627. [CrossRef] [PubMed]

37. Correia, V.C.S.; Garnero, A.D.V.; dos Santos, L.P.; Silva, R.R.; Barbosa, M.; Bonifácio, H.L.; Gunski, R.J. Alta similaridade cariotípica na família Emberezidae (Aves: Passeriformes). Biosci. J. 2009, 25, 99-111.

38. Völker, M.; Backström, N.; Skinner, B.; Langley, E.J.; Bunzey, S.K.; Ellegren, H.; Griffin, D.K. Copy number variation, chromosome rearrangement, and their association with recombination during avian evolution. Genome Res. 2010, 20, 503-511. [CrossRef]

39. Hooper, D.M.; Price, T.D. Chromosomal inversion differences correlate with range overlap in passerine birds. Nat. Ecol. Evol. 2017, 1, 1526-1534. [CrossRef]

40. Nishida-Umehara, C.; Tsuda, Y.; Ishijima, J.; Ando, J.; Fujiwara, A.; Matsuda, Y.; Griffin, D.K. The molecular basis of chromosome orthologies and sex chromosomal differentiation in palaeognathous birds. Chromosome Res. 2007, 15, 721-734. [CrossRef]

41. Stitou, S.; Burgos, M.; Zurita, F.; Jimenez, R.; Sanchez, A.; De La Guardia, R.D. Recent evolution of NOR-bearing and sex chromosomes of the North African rodent Lemniscomys barbarus. Chromosome Res. 1997, 5, 481-485. [CrossRef] 